\title{
Effects of breed, haemoglobin and potassium polymorphism on blood biochemical profiles of agro- pastoral goats
}

\author{
Sam, I. M.*, Ukpanah, U. A., Eyoh, G. D. and Ekpo, J. S. \\ Department of Animal Science, Faculty of Agriculture, Akwa Ibom State University, Akwa Ibom State, Nigeria. \\ ${ }^{*}$ Corresponding author. Email: sidorenyin@yahoo.com
}

Copyright (C) 2018 Sam et al. This article remains permanently open access under the terms of the Creative Commons Attribution License 4.0, which permits unrestricted use, distribution, and reproduction in any medium, provided the original work is properly cited.

Received 26th December, 2017; Accepted 29th January, 2018

\begin{abstract}
This study was conducted to determine the effects of breed, haemoglobin $(\mathrm{Hb})$ and potassium $(\mathrm{k})$ types on blood profiles of agro-pastoral goat herds in North-Western Nigeria. A total of two hundred and fifty (250) agropastoral lactating does comprising of 109 Red Sokoto (RS), 26 Sahel (SH), 34 Kano Brown and 81 Crosses (CRS) were involved in the study. Blood was sampled from all the animals and analysed for packed cell volume (PCV), haemoglobin concentration [Hb], sodium (Na), total protein (TP), albumin (Alb), globulin (Glob) and glucose (Glu). The effects of breed, haemoglobin and potassium types on blood biochemical profile were determined using General Linear Model (GLM) procedures of SAS, significant means were separated using Duncan Multiple Range Test. The electrophoretic analysis showed three haemoglobin genotypes $\mathrm{HbAA}, \mathrm{HbAB}$ and $\mathrm{HbBB}$ and two potassium types were observed; low potassium (LK) and high potassium (HK). The results showed that all the blood parameters measured were within the range of normal values of serum electrolytes of goats. The breeds of goats had no significant influence on blood biochemical profiles sampled except Sahel goats which had higher Total Protein $(64.44 \pm 0.49 \mathrm{~g} / \mathrm{l})$ and Albumin $(31.12 \pm 0.37 \mathrm{~g} / \mathrm{l})$. It was concluded that haemoglobin and potassium types had no influence on blood biochemical profile of the herd of goat studied.
\end{abstract}

Keywords: Agro-pastoral, goats, blood biochemical profile, haemoglobin, potassium.

\section{INTRODUCTION}

Goat breeds constitute the largest number of ruminants in Nigeria and are considered as perfect animals to keep due to their high ability to survive under severely harsh conditions and due to their ability to produce high-quality meat and milk (Akpa et al., 2002). The population of goats in Nigeria has been estimated to be about 53.8 million (FAOSTAT, 2008). In Nigeria, there are many breeds of goat, which include West African dwarf, Red Sokoto, Sahel, Kano brown and some crosses. Three of these breeds are most common in guinea savannah region of the country and they include Red Sokoto, Sahel, Kano brown and their crosses (Sam, 2012).

It is important to determine the blood biochemical profiles because they provide valuable information about the breed, sex and animal's health status (Mandan et al., 2016). Several researchers have documented information on the normal values of blood parameters in domestic animal species (Ewuola et al., 2017; Isaac et al., 2013; Isidahomen et al., 2011; Alderson, 1992; Obi and Anosa, 1980; Bhergariu et al., 1984) and changes in these parameters have been studied in cattle (Gherguiru et al., 1984; Essien et al., 2011), sheep (Vihan and Rai, 1987; Gurcan et al., 2010) and goats (Tambuwal et al., 2002; Ovuru and Ekweozor, 2004; Opara et al., 2010). But the values vary according to the growth requirements, breeds and age (Piccione et al., 2007), environmental factors, managemental conditions (Arfuso et al., 2016), sexual maturity (Piccione et al., 2012), and the productivity of the animals (Mandan et al., 2016). The physiological adaptation and the systemic relationship are widely determined using the haematological values (Shah et al., 2007).

Biotechnology has opened a completely new area at molecular levels with the introduction of electrophoresis 
employed for detection of polymorphism at protein and enzyme loci for the measurement of variations in animals (Salako et al., 2007). Data obtained from this type of study would be useful as genetic markers for important economic characteristics and could aid significantly in the selection of superior animals for breeding purposes (Salako et al., 2007). Haemoglobin and potassium typing are very important as different $\mathrm{Hb}$ and potassium types may have selective advantage in different geographical regions (Ndamukong, 1995). Blood biochemical profiles are also important and reliable for assessing the health status of individual animal (Bhat et al., 2011; Bhat et al., 2014). Despite the importance of goat in the country, very little is known on the effect of breeds on blood parameters and the relationship between hemoglobin and potassium polymorphism with blood biochemical profiles. Therefore, the aim of this study is to determine the relationship between breed, hemoglobin and potassium types with blood profiles.

\section{MATERIALS AND METHODS}

\section{Study area}

This study was carried out in Jigawa and Katsina states within the Sudan savannah zone of North-West Nigeria. Katsina lies between latitude $11^{\circ} 30^{\prime}$ to $13^{\circ} 01^{\prime}$ north of the Equator and longitude $07^{\circ} 41^{\prime}$ to $10^{\circ}$ east of Greenwich Meridian. It is situated at an altitude of $464 \mathrm{~m} \mathrm{(1525 \textrm {ft } )}$ above sea level. The climate varies considerably according to the season. The seasons are cool dry (harmattan) season (December to February); hot dry season (March to May); warm wet season (June to September); a less marked season after rains during the months of October to November, characterized by decreasing rainfall and a gradual lowering of temperature. The mean annual rainfall is about $780 \mathrm{~mm}$. Katsina State is hot for most parts of the year, even during the wet season. Mean annual temperatures range between $19^{\circ}$ in the cold dry season to $38^{\circ}$, with the highest temperatures normally experienced in April and May, just before the rains (Ati et al., 2007). Jigawa State falls within latitude $11^{\circ}$ to $13^{\circ} \mathrm{N}$ and Longitude $8^{\circ}$ to $10^{\circ} \mathrm{E}$. The mean annual rainfall varies from $500 \mathrm{~mm}$ to $1000 \mathrm{~mm}$. Rainfall is higher in the Southern part of the State. The mean daily maximum and minimum temperatures are $35^{\circ} \mathrm{C}$ and $19^{\circ} \mathrm{C}$, respectively. The maximum temperature has two peaks occurring in April and October. The lowest temperatures are recorded during the month of December and January. At this period the temperature can fall as low as $10^{\circ} \mathrm{C}$ or lower at night. The mean relative humidity can be as high as $80 \%$ in the month of August and as low as $15 \%$ in December. The State has an altitude of between 400 to $600 \mathrm{~m}$ above sea level. There are two seasons in Jigawa State namely: rainy and dry seasons with the dry season lasting from November to May and the rainy season lasting between June and October (Wikipedia, 2017).

\section{Management of experimental animals}

The goats were managed under the rural agro-pastoral system of management. The animals were taken out to graze every morning from 8.00 am to $5.00 \mathrm{pm}$ by children and were penned at night. On return from grazing, the animals were penned in small open sided shades by tethering. Before setting out for grazing every morning, the goats were given water and supplements which include groundnut haulms, cowpea haulms and dry grasses. Each animal was tagged with a number for individual identification. The breeds were identified by peculiar characteristics as described by Ngere (1985).

\section{Blood collection and analysis}

Five (5) $\mathrm{ml}$ of blood was collected from each of the sampled animals by jugular venipuncture, using sterile needle and syringe into test tube containing Ethylene Diamine Tetra Acetic acid (EDTA) anticoagulant and samples were properly labeled. Samples were carried in cold pack to haematological laboratory of Bayero University Teaching Hospital Kano, Nigeria for analysis. The blood samples were then washed with normal saline and haemolysed with distilled water to release the haemoglobin. The supernatant was removed after centrifuging at $3000 \mathrm{rpm}$ for 5 minutes and the sample haemoglobin stored until ready for electrophoresis. Cellulose acetate paper strip was used to separate the globin fractions. Electrophoresis was carried out in Shandon electrophoresis tank on cellulose acetate strips $34.5 \times 150$ with $0.26 \mathrm{MTris}$ buffer $(\mathrm{pH} 9.1)$ at the anode and cathode. The strips were run for 5 minutes at a constant voltage of $250 \mathrm{~V}$ until a clear separation was observed. Interpretations were made based on the relative mobility of the haemoglobin bands towards the anode. The genotype that migrated faster was labeled $\mathrm{HbAA}$, the slow moving fraction was identified as $\mathrm{HbBB}$. The double band, consisting of both fast and slow band; was labeled $\mathrm{HbAB}$ as described by Tella et al. (2000) and Das et al. (2004).

Haematocrit value (\%) was determined by the microhematocrite method as described by Burtis and Ashwood (1994). The blood samples were centrifuged at $10,000 \mathrm{rpm}$ for 5 minutes within two hours after the blood samples were collected. The haemoglobin concentration was determined by cyanmethemoglobin method. The potassium and sodium concentrations in the blood were determined by colorimetric method using spectrophotometer. The erythrocyte potassium $(\mathrm{Ke})$ below or equals to $13.00 \mathrm{mmol} / \mathrm{L}$ was labeled Low Potassium (LK). Conversely, the erythrocyte potassium above 13 $\mathrm{mmol} / \mathrm{L}$ was labeled High Potassium (HK) (Galip and Elmaci, 2001). Total protein was obtained using Biuret method as explained by Tietz (1995). Glucose level was determined after enzymatic oxidation in the presence of glucose oxidase as described by Barham and Trinder (1972). Measurement of albumin was based on its 
Table 1. Blood Biochemical profiles of goats in Katsina and Jigawa States (Mean \pm se).

\begin{tabular}{lccccc}
\hline Characteristic & No & Mean \pm se & CV & Min & Max \\
\hline $\mathrm{PCV}(\%)$ & 250 & $28.48 \pm 0.28$ & 15.03 & 4.00 & 42.00 \\
$\mathrm{Hb}(\mathrm{g} / \mathrm{dl})$ & 250 & $9.49 \pm 0.09$ & 15.58 & 4.66 & 14.00 \\
$\mathrm{Na}(\mathrm{Mmol} / \mathrm{L})$ & 250 & $136.40 \pm 0.42$ & 6.02 & 125.00 & 141.00 \\
$\mathrm{TP}(\mathrm{g} / \mathrm{L})$ & 250 & $64.44 \pm 0.49$ & 12.21 & 46.00 & 94.00 \\
Albumin $(\mathrm{g} / \mathrm{L})$ & 250 & $31.12 \pm 0.37$ & 18.32 & 20.00 & 51.00 \\
Globulin $(\mathrm{g} / \mathrm{L})$ & 250 & $33.12 \pm 0.60$ & 28.72 & 13.00 & 65.00 \\
Glucose $(\mathrm{g} / \mathrm{l})$ & 250 & $4.45 \pm 0.04$ & 14.92 & 2.80 & 6.60 \\
\hline
\end{tabular}

$\mathrm{CV}=$ Coefficient of variation, $\mathrm{PCV}=$ packed cell volume, $\mathrm{Hb}=$ haemoglobin concentration, $\mathrm{Na}=$ sodium, $\mathrm{TP}=$ Total protein.

Table 2. Blood biochemical profiles of goats according to location (Means \pm se).

\begin{tabular}{lccc}
\hline Blood biochemical profiles & Jigawa & Katsina & LOS \\
\hline [HB] $(\mathrm{g} / \mathrm{dl})$ & $8.98 \pm 0.12^{\mathrm{b}}$ & $10.27 \pm 0.13^{\mathrm{a}}$ & $* *$ \\
$\mathrm{PCV}(\%)$ & $26.91 \pm 0.33^{\mathrm{b}}$ & $30.86 \pm 0.39^{\mathrm{a}}$ & $* *$ \\
$\mathrm{~K}(\mathrm{mmol} / \mathrm{L})$ & $19.95 \pm 1.39$ & $18.48 \pm 0.39$ & $\mathrm{Ns}$ \\
$\mathrm{Na}(\mathrm{mmol} / \mathrm{L})$ & $138.36 \pm 0.54$ & $136.96 \pm 0.64$ & $\mathrm{Ns}$ \\
Total protein $(\mathrm{g} / \mathrm{L})$ & $65.27 \pm 0.60$ & $63.20 \pm 0.83$ & $\mathrm{Ns}$ \\
Albumin $(\mathrm{g} / \mathrm{L})$ & $31.28 \pm 0.50$ & $31.50 \pm 0.51$ & $\mathrm{Ns}$ \\
Globulin $(\mathrm{g} / \mathrm{L})$ & $34.07 \pm 0.74$ & $31.70 \pm 0.99$ & $\mathrm{Ns}$ \\
Glucose $(\mathrm{g} / \mathrm{L})$ & $4.67 \pm 0.04$ & $4.11 \pm 0.09$ & $\mathrm{Ns}$ \\
\hline
\end{tabular}

${ }^{* *}=\mathrm{p}<0.001, \mathrm{a}, \mathrm{b}=$ means within the same row with different superscripts differ significantly, $\mathrm{n}=\mathrm{no}$ of observation, ns = not significant, LOS = level of significance.

quantitative binding to the indicator 3,3,5,5-tetrabromo-mcresol sulphonephthalein (bromocresol green, BCG) (Grant et al., 1987). Globulin concentration was calculated from total protein and albumin, by subtracting albumin from total protein.

\section{Statistical analysis}

The data generated from the study were analyzed using General Linear Model (GLM) procedure of SAS (SAS, 2000). The model incorporated Breed, Hb-type and K-type as fixed factors while biochemical profiles were the dependent variables. Duncan Multiple Range Test (DMRT) procedure of SAS was used to separate the significant means. The linear model was as follows:

$Y_{i j \mid n}=\mu+H_{i}+K_{j}+B_{k}+E_{i j k}$

Where: $Y_{\mathrm{ijl}}=$ Measurement on traits, $\mu=$ Population mean, $\mathrm{H}_{\mathrm{i}}=$ Effect of $i^{\text {th }}$ haemoglobin types $(i=A A, A B, B B),, K_{j}=$ Effect of $j^{\text {th }}$ potassium types $(j=L k, H k), B_{k}=E f f e c t$ of $k^{\text {th }}$ Breed $(k=R S, B W, C R S, K B), E_{i j}=$ Random error effect.

The t-test analysis was used to test the differences between the two locations.

\section{RESULTS AND DISCUSSION}

\section{Blood profiles of the study goats}

The means and coefficient of variation (CV) for concentration of blood biochemical profiles of the studied agro-pastoral goats are presented in Table 1. The average $\mathrm{PCV}, \mathrm{Hb}, \mathrm{Na}$, total protein, albumin, globulin and glucose were $28.48 \%, 9.49 \mathrm{~g} / \mathrm{dl}, 136.40 \mathrm{mmol} / \mathrm{l}, 64.44 \mathrm{~g} / \mathrm{L}, 31.12$ $\mathrm{g} / \mathrm{L}, 33.12 \mathrm{~g} / \mathrm{L}$ and $4.45 \mathrm{~g} / \mathrm{L}$, respectively. Measures of blood biochemical profile exhibited low to moderate variability (from 6.02 to 28.72 ). The lowest variability was recorded for $\mathrm{Na}$ concentration while the highest was globulin concentration. There were no significant $(P>0.05)$ difference between blood biochemical profiles of goats across locations (Table 2).

Breed of goats had non-significant $(P>0.05)$ effect on all the blood biochemical profiles measured except $\mathrm{Na}$, total protein and albumin (Table 3). Na concentrations in Kano brown was significantly $(P>0.05)$ higher than Sahel, but statistically like other breeds. The Sahelian goats had the highest total protein and was significantly $(\mathrm{P}<0.05)$ higher than the concentration in the crosses, but like the concentration in the Red Sokoto and Kano Brown. All the blood biochemical constituents measured were within the range of normal values of serum electrolytes of goats as 
Table 3 Blood biochemical profiles of goats (Mean values $\pm s e$ ) in Jigawa and Katsina States according to breed.

\begin{tabular}{lccccccc}
\hline \multirow{2}{*}{ Breed } & \multicolumn{7}{c}{ Factors } \\
\cline { 2 - 8 } & $\mathbf{P C V}(\%)$ & $\mathbf{H b}(\mathbf{g} / \mathbf{d} \mathbf{l})$ & $\mathbf{N a}(\mathbf{M m o l} / \mathbf{L})$ & $\mathbf{T P}(\mathbf{g} / \mathbf{L})$ & Alb $\mathbf{~ g / L )}$ & Glob $(\mathbf{g} / \mathbf{L})$ & $\mathbf{G l u}(\mathbf{g} / \mathbf{L})$ \\
\hline Crs & $26.87 \pm 0.51$ & $8.96 \pm 0.18$ & $133.67 \pm 0.77^{\mathrm{ab}}$ & $64.09 \pm 0.91^{\mathrm{b}}$ & $31.71 \pm 0.67^{\mathrm{ab}}$ & $32.56 \pm 1.10$ & $4.720 \pm 0.08$ \\
Sh & $26.67 \pm 2.57$ & $8.89 \pm 0.89$ & $125.67 \pm 387^{\mathrm{b}}$ & $73.00 \pm 4.55^{\mathrm{a}}$ & $35.67 \pm 3.34^{\mathrm{a}}$ & $37.33 \pm 5.53$ & $4.800 \pm 0.39$ \\
RS & $29.28 \pm 1.99$ & $9.77 \pm 0.77$ & $135.26 \pm 0.52^{\mathrm{ab}}$ & $64.45 \pm 0.61^{\mathrm{ab}}$ & $31.36 \pm 0.45^{\mathrm{ab}}$ & $33.09 \pm 0.85$ & $4.325 \pm 0.06$ \\
Kb & $25.60 \pm 2.10$ & $8.53 \pm 8.53$ & $139.20 \pm 3.00^{\mathrm{a}}$ & $66.20 \pm 3.53^{\mathrm{ab}}$ & $25.60 \pm 2.59^{\mathrm{b}}$ & $32.56 \pm 4.29$ & $4.200 \pm 0.31$ \\
\hline
\end{tabular}

${ }^{*} \mathrm{P}<0.05 ; \mathrm{a}, \mathrm{b},=$ column means under the same factor with different superscripts differ significantly, Crs $=\mathrm{crosses}, \mathrm{Sh}=\mathrm{Sahel}$, RS $=\mathrm{Red} \mathrm{Sokoto}$, $\mathrm{Kb}=$ Kano brown, $\mathrm{PCV}=$ packed cell volume, $\mathrm{Hb}=$ haemoglobin concentration, $\mathrm{Na}=\mathrm{Sodium}, \mathrm{TP}=$ Total protein, Alb $=\mathrm{Albumin}, \mathrm{Glob}=$ globulin, $\mathrm{Glu}$ $=$ glucose.

reported by Boyd (1984) and Radostits et al. (200).

The percentage of PCV (28.47\%) in this study was like the $29.4 \%$ obtained by Daramola et al. (2005) in WAD goats. However, this is higher than $25.7 \%$ obtained in Red Sokoto goats by Tambuwal et al. (2002). Earlier reports in Baladi goats (Azab and Abdel-Maksoud, 1999) showed PCV values of $27.25 \%$. The $\mathrm{Hb}$ concentration in this study $(9.49 \mathrm{~g} / \mathrm{dl})$ was within the range of normal values obtained in Red Sokoto goats which is 7 to $15 \mathrm{~g} / \mathrm{dl}$ (Tambuwal et al., 2002; Daramola et al., 2005). This is an advantage in terms of oxygen carrying capacity of the blood, which may lead to better functioning and performance of these animals.

The $\mathrm{Na}$ concentration obtained in this study (136.40 $\mathrm{mmol} / \mathrm{L}$ ) is within the range reported in WAD goats and Red Sokoto goats by Daramola et al. (2005) and Tambuwal et al. (2002) respectively. Sodium makes up about $93 \%$ of the basic mineral elements in the blood serum and is chief cation regulating blood $\mathrm{pH}$ (Swartz, 2010). The ability of muscles to contract is dependent on proper sodium concentration. Therefore, these indigenous goats could be said to have normal sodium concentration in the blood. Total protein in this study $(64.44 \mathrm{~g} / \mathrm{l})$ was within the range reported by Tambuwal et al. (2002) in Red Sokoto goats and Oduye and Adadevoh (1976) reported same in WAD sheep. Lower concentration of albumin was observed in KB when compared to Sahel goat, although it was similar to other breeds sampled albumin concentration in this study $(33.12 \mathrm{~g} / \mathrm{L})$ was within the range reported by other authors (25 to $34 \mathrm{~g} / \mathrm{l}$ ) (Oduye and Adadevoh, 1976; Tambuwal et al., 2002; Daramola et al., 2005).

Proteins are the basic components of enzymes, many hormones, antibodies and clotting agents. They are substance that aid in the transportation of hormones, vitamins, minerals, lipids and other materials (Kaslow, 2011; Njidda et al., 2014). In addition, proteins help balance the osmotic pressure of the blood and tissue (Kaslow, 2011). Total protein in the blood which represents the sum of albumin and globulin is a very strong indicator of the health status of the animals; low albumin is a sign of poor health (Ewuola et al., 2017). Serum total protein is not related to the amount of calories contained in diets but to the availability of protein for utilization (Tewe and Maner, 1980). Globulin and glucose concentration were similar for all the breeds sampled. The glucose concentration (4.44 $\mathrm{g} / \mathrm{l})$ observed in this study is higher than $2.3 \mathrm{mmol} / \mathrm{L}$ and $3.9 \mathrm{mmol} / \mathrm{L}$ in the study of Jovanovic et al. (1998) and McDongall et al. (1991), respectively. Zubcic (2001) established that glucose level decreases with age of goats, and most of the animals in this study were between ages 2 to 6 years which probably explains the high concentration of glucose. Glucose is the major precursor of lactose synthesis in the mammary gland, and lactose is the major carbohydrate and osmolyte of milk which controls milk volume and its concentration (Shahbazkial et al., 2010).

\section{Effect of haemoglobin and potassium polymorphism on blood profiles in goats}

Table 4 shows blood profiles of goats based on haemoglobin and potassium types. The $\mathrm{Hb}$ type significantly $(P<0.05)$ influenced PCV; animals with $\mathrm{HbAA}$ had significantly $(P<0.05)$ higher $P C V$ values than those with $\mathrm{HbAB}$ and $\mathrm{HbBB}$ which were statistically similar. Haemoglobin concentration $(\mathrm{Hb})$ was also significantly influenced by $\mathrm{Hb}$ types, animals with $\mathrm{HbAA}$ had significantly $(\mathrm{P}<0.05)$ higher concentration of haemoglobin $(\mathrm{Hb})$ than animals with $\mathrm{HbAB}$ and $\mathrm{HbBB}$. Hb-type had no significant $(P>0.05)$ influence on $\mathrm{Na}$, total protein, albumin, globulin and glucose. On the other hand, potassium types have no significant $(P>0.05)$ effect on all the blood profiles measured except on $\mathrm{Na}$. HK animals had significantly $(\mathrm{P}<0.05)$ lower $\mathrm{Na}$ concentration than $\mathrm{LK}$ potassium animals.

In the present study, $\mathrm{Hb}$ type only influenced packed cell volume (PCV) and haemoglobin concentration, animals with $\mathrm{HbAA}$ recorded higher values of $\mathrm{PCV}$ than animals with $\mathrm{HbAB}$ and $\mathrm{HbBB}$. Carriers of haemoglobin $\mathrm{AA}$ genotype have been reported to have better functional properties such as affinity for oxygen, higher haemoglobin concentration and packed cell volume (FAO, 2008; Akinyemi and Salako, 2010)

The effect of potassium types significantly influenced $\mathrm{Na}$ concentration. It had been observed that $\mathrm{HK}$ animals had less concentration of Na than LK (Galip and Elmaci, 2001). This observation agrees with the reports of Gurcan et al. 
Table 4. Blood biochemical profiles of Goats based on haemoglobin and potassium type.

\begin{tabular}{lccccccc}
\hline Factor & PCV $\%$ & Hb $\mathbf{~ g / d l ~}$ & Na Mmol/L & TP $\mathbf{~} / \mathbf{L}$ & Alb g/L & Glob g/L & Glu $\mathbf{~ g / L ~}$ \\
\hline H-type & & & & & & & \\
HbAA & $29.95 \pm 0.42^{\mathrm{a}}$ & $10.00 \pm 0.15^{\mathrm{a}}$ & $133.76 \pm 0.64$ & $65.25 \pm 0.76$ & $31.34 \pm 0.56$ & $34.00 \pm 0.92$ & $4.46 \pm 0.06$ \\
HbAB & $27.36 \pm 0.42^{\mathrm{b}}$ & $9.12 \pm 0.15^{\mathrm{b}}$ & $136.68 \pm 0.63$ & $64.09 \pm 0.74$ & $31.47 \pm 0.55$ & $32.64 \pm 0.90$ & $4.48 \pm 0.06$ \\
HbBB & $27.33 \pm 0.81^{\mathrm{b}}$ & $9.11 \pm 0.28^{\mathrm{b}}$ & $137.67 \pm 1.22$ & $62.87 \pm 1.43$ & $31.10 \pm 1.10$ & $31.77 \pm 1.74$ & $4.31 \pm 0.12$ \\
& & & & & & & \\
K-type & & & & & & & \\
HK & $28.32 \pm 0.31$ & $9.45 \pm 0.11$ & $134.03 \pm 0.46^{\mathrm{b}}$ & $64.56 \pm 0.54$ & $31.39 \pm 0.39$ & $33.62 \pm 0.66$ & $4.48 \pm 0.05$ \\
LK & $29.31 \pm 0.71$ & $9.76 \pm 0.25$ & $138.41 \pm 1.03^{\mathrm{a}}$ & $63.85 \pm 1.26$ & $33.39 \pm 0.39$ & $30.46 \pm 1.53$ & $4.25 \pm 0.20$ \\
\hline
\end{tabular}

$\mathrm{PCV}=$ packed cell volume, $\mathrm{Hb}=$ haemoglobin concentration, $\mathrm{Na}=$ sodium, $\mathrm{TP}=$ total protein, Glob=globulin, $\mathrm{Glu}=\mathrm{glucose}$.

(2010) that noted significant difference in the mean $\mathrm{Na}$ concentration of $\mathrm{HK}$ and $\mathrm{LK}$, which they observed to be 174 and $150 \mathrm{mmol} / \mathrm{l}$ for LK and HK, respectively. This variation could be attributed to $\mathrm{Na}-\mathrm{K}$ pump sites per unit cell membrane surface. Shahbabak et al. (2009) explained that HK type animals had low number of $\mathrm{Na}-\mathrm{K}$ pump sites which lead to a lower concentration of $\mathrm{Na}$ in the cell while LK type animals have a higher number of $\mathrm{Na}-\mathrm{K}$ pump sites, hence the increase in $\mathrm{Na}$ concentration of these animals.

\section{Conclusion}

The blood profiles of the studied Agro-pastoral goats were within the reference normal range for goats. The locations of animals have no influence on all the blood parameters analyzed, except on $\mathrm{Hb}$ concentration and PCV. The breeds of goats have no significant influence on blood profiles sampled, except in the Sahel goats which had higher total protein and albumin; but lowest $\mathrm{Na}$ compared to other breeds. Haemoglobin and potassium types also have no influence on all the blood parameters analysed.

\section{CONFLICT OF INTEREST}

The authors declare that they have no conflict of interest.

\section{REFERENCES}

Alderson, G. L. H. (1992). Genetic Conservation of Domestic Livestock. CAD International, Wallingford, UK. p. 242.

Akinyemi, M. O., \& Salako, A. E. (2010). Hemoglobin polymorphism and Morphometrical correlates in the West African Dwarf Sheep of Nigeria. International Journal Morphology, 28(1), 205-208.

Akpa, G. N., Asiribo, D. E., Oni, O. O., Alawa, J. P., Dim, N. I., Osinowo, O. A., \& Abubakar, B. Y. (2002). Milk Production by Agropastoral Red Sokoto goats in Nigeria. Tropical Animal Health and Production, 34, 525-533.

Arfuso, F., Fazio, F., Rizzo, M., Marafioti, S., Zanghì, E., \& Piccione, G. (2016) Factors affecting the hematological parameters in different goat breeds from Italy. Ann. Anim. Sci., $16,743-757$.

Ati, O. F., Iguisi, E. O., \& Afolayan, J. O. (2007). Are we experiencing drier conditions in the Sudano Sahelian Zone of
Nigerian? Journal of Applied Sciences Research, 3(12), 17461751.

Azab, M. E., \& Abdel-Maksoud, H. A. (1991), changes in some haematological and biochemical parameters during perpartum and post - Partum periods in Female Baladi Goats. Small Ruminant Research, 34, 77-85.

Babatunde, G. M, Pond, W.O, Krook, L., Dvan, L, Walker, E.R. and Chapman, D. (1987). Effect of dietary safflower oil or hydrogenated coconut oil on growth rate and on swine blood and tissue components of pigs fed fat free diet. $J$. of nutria, 3(1), 29-33.

Barham, D., \& Trinder P. (1972). An improve colour reagent for determination of blood glucose by oxidase system. Analyst, 97, 142-145.

Bhat, S. A., Mir, M. U. R., \& Qadri, S. (2011). Hematological and biochemical parameters of Kashmiri goats in different climatic conditions. International Journal for Agro Veterinary and Medical Sciences, 5, 481-487.

Bhat, S. A., Mir, M. R., Reshi, A. A., Ahmad, S. B., Husain, I., Bashir, S., \& Khan, H. M. (2014). Impact of age and gender on some blood biochemical parameters of apparently healthy small ruminants of sheep and goats in Kashmir valley India. International Journal of Agricultural Sciences and Veterinary Medicine, 2(1), 22-27.

Bhergariu, S., Rowlands, G. J., Danielescu., A. L., Pop., N., \& Moldova, A. (1984). A comparative study of metabolic profiles obtained in dairy sheep in Romania. British Veterinary Journal, 140: 600-608.

Boyd, J. W. (1984). The interpretation of serum biochemistry test results in domestic animals, in Veterinary Clinical Pathology, Veterinary Practice Publishing Co., 13(2), 34-41.

Burtis, C. A., \& Ashwood, E. R. (1994). Tietz Textbook of Clinical Chemistry. $2^{\text {nd }}$ Edition, W. B. Saunders company, Philadelphia, Pp. 1990-1991.

Daramola, J. O., Adeloye, A. A., Fatoba, T. A., \& Soladoye, A. O. (2005). Haematological and biochemical parameters of West African Dwarf goats. Livestock Research for Rural Development. 17(8), 1-8.

Das, D. K., Sinha, R., Dattagupta, R., \& Senapti, P. K. (2004). Association of Haemoglobin types with some menstruation and reproductive characteristics in Garole sheep. Indian Journal of Animal Sciences, 74(4), 382-384.

Essien, I. C., Akpa, G. N., Barje, P. P., \& Alphonsus, C. (2011). Haemoglobin types in Bunaji cattle and their Friesian crosses in Shika, Zaria-Nigeria. Afri. J. Anim. Biomed. Sci., 6(1), 112116.

Ewuola, E. O., Adeyemi, A. A., \& Bello, O. R. (2017) Variations in haematological and Serum biochemistry indices among 
White Fulani bulls, Ouda rams and West African Dwarf bucks. Nigerian Journal of Animal Production, 44(1), 136-143.

FAO (Food and Agriculture Organization of the United Nations), (2008). FAO Production year book. Rome.

FAOSTAT (2008). The State of Food and Agriculture. http://faostat.fao.org/default.aspx.

Galip, N., \& Elmaci, C. (2001). Erythrocyte potassium polymorphism and relationship with blood parameter in Turkish Hair Goats. Journal of Genetic Breeds, 55, 183-185.

Gherguiru, S., Rowlands, G. J., Danielescu, A. L., Pop, N., \& Moldova, A. (1984). A comparative study of metabolic profiles obtained in Dairy herbs in Romania. British Veterinary Journal, 140, 600-608.

Grant, G. H. Dumas, B. T., \& Watson, W. A. (1987). Fundamentals of clinical chemistry. WB Saunders Company, Pp. 328-329.

SAS (2000). Statistical Analysis system, Version 8.0 SAS Institute Inc. Cary North Carolina, USA.

Gurcan, E. K., Erbas, C., \& Cobanoglue, O. (2010). Biochemical polymorphism of erythrocyte potassium and glutathione protein. The relationship with some blood parameters in Kirvircik sheep breed. African Journal of Agricultural Research, 5, 1022-1027.

Isaac, I. J., Abah, G., Akpan, B., \& Ekaette, I. U. (2013). Haematological properties of different breeds and sexes of rabbits. Proceedings of Animal Science Association of Nigeria. Pp. 24-27.

Isidahomen, E. C., Ikhimioya, I., Njidda, A. A., \& Okoruwa, M. I. (2011). Haematological parameters and Blood Chemistry of different species of Ruminant animals in Humid Tropical Environment. Nigerian Journal of Agriculture and Forestry, 3(1), 85-90.

Jovanovic, J. M. Ivanov, I., Damjanovic, Z., Jovovic, S., Jonic, B., Markovic, S., \& Sirovica, E. (1998). A note of some biochemical constituents of blood in pregnant goats reared on extensive management system. Indian veterinary Journal, 68, 592-594.

Kaslow, J. E. (2011). Proteins - Albumin, Globulins etc. Available:http://www.drkaslow.com/html/proteins_albumin_glo bulins.html.

Mandan, J., Sindhu, S., Gupta, M., \& Kumar, S. (2016). Hematobiochemical profile and mineral status in growing beetal goat kids. J. Cell Tissue Res., 16, 5517-5522.

MacDougall, S., Lepherd, E. E., \& Smith, S. (1991). Haematological and biochemical reference values for grazing Saanen goats. Australian Veterinary Journal, 68, 370-372.

Ndamukong, K. J. (1995). Haemoglobin polymorphism in Grassland dwarf sheep and goats of the North West province of Cameroon. Bulletin of Animal Health and Production in Africa, 43, 53-56.

Njidda, A. A., Shuai'bu, A. A., \& Isidahomen, C. F. (2014). Haematological and Serum Biochemical Indices of Sheep in Northern Nigeria. Global journal of Science Frontier Research, 14(2), 49-56.

Ngere, L. O. (1985). The small ruminants of West Africa - A review. Animal Genetic Resources in Africa. In: Proceedings of the Expert Committee Meeting (Indigenous Livestock of Africa). Bulawayo, Zimbabwe (FAO, ROME), 1998. Pp. 113122.

Obi, T. U., \& Anosa, V. O. (1980). Haematological studies of Domestic animals. IV: Clinicohaemotological features of bovine trypanosomiasis, theileriosis, anaplasmois, epertherosoonosis and helminthiasis. Zenntralblatt fur Vetterina Medizin Relhe, 27(17), 789-797.

Oduye, O. O., \& Adadevoh, B. K. (1976). Biochemical Values of
Apparently normal Nigerian sheep. Nigerian Veterinary Journal, 5(1), 43-50.

Opara, M. N., Udevi, N., \& Okoli, I. C. (2010). Haematological parameters and blood chemistry of apparently healthy West African Dwarf (Wad) goats in Owerri, South Eastern Nigeria. New York Science Journal, 3(8), 68-72.

Ovuru, S. S. and Ekweozor, I. K. E. (2004). Haematological changes associated with crude oil ingestion in experimental rabbits. African Journal if Biotechnology, 3(6), 346-348.

Piccione, G., Borruso, M., Fazio, F., Giannetto, C., \& Caola, G. (2007). Physiological parameters in lambs during the first 30 days postpartum. Small Rumin. Res., 72, 57-60.

Piccione, G., Messina, V., Vazzana, I., Dara, S., Giannetto, C., \& Assenza, A. (2012) Seasonal variations of some serum electrolyte concentrations in sheep and goats. Comp. Clin. Pathol., 21, 911-915.

Radostits, O. M., Gay, C. C., Blood, D. C., \& Hinchcliff, K. W. (2000). The haematological values for cattle, sheep, goatsand pigs. Veterinary Medicine, 9th edn, W.B. Saunders, London, Pp. 1819-1822.

Salako, A. E., ljadunola, T. O., \& Agbesola, Y. O. (2007). Haemoglobin polymorphism in Nigerian Indigenous small ruminant populations preliminary investigation. African Journal Biotechnology, 6(22), 2636-2638.

Sam, I. M. (2012). Relationship of Haemoglobin and Potassium Polymorphism with Conformation, Milk Production and Blood Biochemical Profiles in Agropastoral Goats. Ph. D. Dissertation Ahmadu Bello University Zaria. p. 95.

Shahbazkial, H. R., Aminlari, M., Tavasoli, A., Mohammadnia, A. R., \& Cravador, A. (2010). Associations among milk production traits and glycosylated haemoglobin in dairy cattle; importance of lactose synthesis potential. Veterinary Research Communication, 34,1-9.

Shahbabak, H. M. Shaharbabak, M. M., \& Yeganeh, H. M. (2009). Whole blood potassium polymorphism and other blood electrolytes of varamini sheep in iran. International Journal of Agriculture and Biology, 9(1), 84-86.

Shah, M. K., Khan, A., Rizvi, F., \& Siddique, M. (2007). Effect of cypermethrin on clinico-haematological parameters in rabbits. Pakistan Veterinary Journal, 27(4), 171-175.

Swartz, H. (2010). Importance of salt in the diet of sheep and goats. Goat and sheep news.

Tambuwal, F.M., Agale, B. M., \& Bangana, A. (2002). Haematological and Biochemical values of apparently healthy Red Sokoto goats. Proceeding of the $27^{\text {th }}$ Annual Conference Nigerian Society of Animal Production (NSAP), March, 77-21, 2002, FUTA Akure, Nigeria, Pp. 50-53.

Tella, M. A., Taiwo, V. O., Agbede, S. A., \& Alonge, O. D. (2000). The influence of hemoglobin types of incidence of babesiosis and anaplasmosis in West African Dwarf and Yankasa sheep. Tropical Veterinary Journal, 18, 121-127.

Tewe, O. O., \& Maner, J. H. (1980). Cyanide, Protein and iodine interaction in the physiology and metabolism in rats. Food Chemistry, 9, 95-104.

Tietz, N. W. (1995). Fundamentals of Clinical Chemistry. W.B. Saunder Co., Phila, P.A. p. 874.

Vihan, V. S., \& Rai, P. (1987). Certain haematological and biochemical attributes during pregnancy, parturition and postparturition periods in sheep and goats. Indian Journal of Animal Science, 57(11), 1200-1204.

Zubcic, D. (2001). Some biochemical parameters in blood of grazing German improved fawn goats from Istria, Croatia. VeterinarskiArchiv, 71(5), 237-244. 